\title{
COMPARATIVE CHEMICAL PROFILING OF ESSENTIAL OIL COMPONENTS USING GC-MS IN MICRO, MINI AND MOTHER RHIZOMES OF KAEMPFERIA GALANGA L.
}

\author{
VR Vidya ${ }^{1}$, Padmesh Pillai ${ }^{2}$, TS Preetha* ${ }^{1}$ \\ ${ }^{1}$ Plant Tissue Culture Laboratory, Department of Botany, University College, Thiruvananthapuram, Kerala, Research Centre, \\ University of Kerala \\ ${ }^{2}$ Departmenat of Genomic Science, School of Biological Science, Central University of Kerala, Periye, Kasaragod Kerala, India \\ *Corresponding author: preethahemanth@yahoo.com
}

\begin{abstract}
Kaempferia galanga L. is a pharmaceutically and traditionally important medicinal plant. Its rhizomes are having potential demand in ayurvedic drug preparation. The study presented here reports the essential oil components analysed using GC-MS in three samples of $K$. galanga such as the microrhizomes raised through tissue culture technique, the mini rhizomes harvested from the field transferred tissue culture-derived plants and the mother rhizomes, which are the stock plants (control). Potent bioactive compounds like ethyl-p-methoxycinnamate, ethyl cinnamate, borneol and pentadecane were detected in the samples. The amount ethyl p- methoxycinnamate was very high in microrhizome (58.088\%) and minirhizome oil (31.24\%) as compared to in vivo mother rhizome. The amount of ethlyl cinnamate was $9.21 \%$ in microrhizome oil and it increased to $39.42 \%$ in minirhizome oil. Pentadecane recorded $1.482 \%$ in microrhizome and its amount increased to $4.49 \%$ in minirhizome oil, while the amount was noticed in in vivo mother rhizome. Borneol was analysed from micro (1.349\%) and minirhizome oil (3.57\%) samples but it was absent in mother rhizome. In our study, in vitro microrhizome and minirhizomes essential oil depicted superior quality in terms of the bioactive compounds and was on par with the mother rhizome oil. The in vitro production methodology developed here would help in the large scale production of pharmacologically important components from K. galanga.
\end{abstract}

Keywords: Essential oil, Kaempferia galanga, Microrhizomes, Minirhizomes, Mother rhizomes, GC-MS, Ethyl cinnamate, Ethyl p-methoxycinnamate.

\section{INTRODUCTION}

Kaempferia galanga is an endangered medicinal plant of family Zingiberaceae [1] locally called as Chandramulika, Karchoor, sugandhvacha, resurrection lily, and aromatic ginger. The species is mostly cultivated in south-east Asian countries viz. China, Malaysia, Thailand, Indonesia, and India. Leaves, rhizomes and root tubers are the medicinally important parts of the plant. Leaves are used for flavouring foodstuffs, preparing mouth washes and hair tonic, they are antinociceptive and antiulcerative [2, 3]. Rhizomes are the officially useful parts which are used for curing bronchitis, asthma, malaria, skin disease, wounds and spleenic disorders [4]. Moreover, they are constituents of a variety of Ayurvedic preparations like Dasamularista, Valiyarasnadikasaya, kaccoradichurna, Asanaeladitaila and Valiyanarayanataila [5]. In Indonesia and Malaysia, traditional herbal preparation, known as 'Makjun' and 'Jamu', are consumed frequently for beneficial health effect [6]. They are used for the preparation of decoction or powders, which are used for indigestion, cold, pectoral pain, abdominal pain, headache and toothache [7]. Thus the plant is an economically important species which forms the main ingredient of many ayurvedic drugs used for the healing of rheumatism [8] and the aromatic essential oil extracted from the rhizome is a valuable component of perfume production. The essential oil compounds were analyzed earlier in its rhizome by many workers and the plant contains 2.4 to $3.9 \%$ volatile oil $[9,10]$. Essential oil from the rhizomes was found active against gram positive and gram negative microorganisms $[11,12]$ and hence it could be used for the skin infections and microbial diseases [13]. Also, it is a good natural source of a biologically active ester compound ethyl pmethoxycinnamate, which was found to exhibit anticancer activity [14]. Ethyl cinnamate and ethyl pmethoxycinnamate, are the most active compounds in essential oil of $K$. galanga [13, 15]. The price of the 
essential oil of the plant varies from US $\$ 600$ to 700 per $\mathrm{kg}$ on the international market, and this plant is over exploited by local people and pharmaceutical companies. The essential oil is used in Bangladesh for fragrance in vinegar, hair washes, cosmetic powders, flavoring the foodstuffs and beverages [16].

In addition, $K$. galanga plant has been reported to have broad-spectrum pharmacological and biological activities including antioxidant [17] larvicidal [18]), antibacterial [19], sedative [20], antineoplastic [21], vasorelaxant [22] and nematicidal [23] effects. Thus there are a number of reports on the bioactive potentialities, in vitro propagation and conservation of the species. As the rhizomes of the species are having potential demand in pharmaceutics, other routes of material production needs to be formulated to avoid further scarcity of the same due to over exploitation. Biotechnological methods using plant tissue culture technology have offered the production of in vitro clones in this taxa [24]. However, an analysis of the phytocomponents of the microrhizomes and minirhizomes that were derived from the in vitro procedures were not attempted yet. The present investigation reports the induction of microrhizomes, minirhizomes and comparison of chemical constituents in the essential oil of the same in Kaempferia galanga.

\section{MATERIAL AND METHODS}

\subsection{Plant Material}

Rhizomes of Kaempferia galanga L. collected from Kundara, Kollam District, Kerala State, India, was used as the plant material for the in vitro microrhizome induction and essential oil extraction.

\subsection{Production of micro and mini rhizomes}

Rhizomes containing axillary buds were inoculated aseptically in MS medium containing $0.5 \mathrm{mgl}^{-1}$ BA according to the standardized procedure [25]. Initiated shoots were multiplied in MS medium augmented with $3.0 \mathrm{mgl}^{-1} \mathrm{BA}$ and $0.5 \mathrm{mgl}^{-1} \mathrm{NAA}$. For in vitro microrhizome induction, the in vitro shoots established in $3.0 \mathrm{mgl}^{-1} \mathrm{BA}$ and $0.5 \mathrm{mgl}^{-1} \mathrm{NAA}$ were then subcultured to the fresh medium of the same composition augmented with different concentration of silver nitrate $\left(1.0 \mathrm{mgl}^{-1}\right.$ and $\left.2.0 \mathrm{mgl}^{-1}\right)$ and sucrose $(3,6$ and $9 \%)(\mathrm{w} / \mathrm{v})$. After six months, the in vitro microrhizomes were collected and washed in running tap water to remove all the remnants of culture medium and were used for essential oil extraction. The in vitro plantlets were planted in polythene bags filled with garden soil and river sand (3:1) and maintained in the green house and regular watering for the production of minirhizomes. After six months period, the minirhizomes were collected for further analysis.

\subsection{Extraction of essential oil}

Twenty five grams each of microrhizomes collected from the culture vessel, minirhizomes collected from the green house and in vivo mother rhizomes collected from the field (control) were subjected to hydrodistillation using a modified Clevenger-type glass apparatus for 4hours for isolation of essential oils separately.

\subsection{GC-MS analysis}

The GC-FID analysis was carried out on a Varian CP3800 gas chromatograph equipped with flame ionaisation detector (FID) and a CP Sil 8CB fused silica capillary column (30 m×0.32 mm, film thickness-0.25 mm). Nitrogen was used as carrier gas at flow rate $1 \mathrm{ml} / \mathrm{min}$. The oil constituents were identified by MS library search (WILEY 275), comparison of the relative retention indices were calculated with respect to homologous of $\mathrm{n}$-alkanes $\left(\mathrm{C}_{6}-\mathrm{C}_{30}\right.$, Aldrich Chem. Co. Inc) [26] and comparison of mass spectrum reported in the literature [27].

\section{RESULTS AND DISCUSSION}

Essential oils collected from in vivo rhizomes (control), in vitro microrhizomes and minirhizomes of $K$. galanga analysed by GC-MS (Figs. 1-3) and the components present were presented in Tables 1-6. As per GC-MS analysis, there were 79 components in in vivo rhizome oil. The major compounds detected in the mother rhizomes and their reported bioactivities are given in Tables 1 and 2. Palmitic acid (12.23\%) was detected as the predominant compound in addition to capric acid (8.96\%), caprylic acid (4.47\%), lauric acid (3.08\%), myristic acid (3.92\%), stearic acid (3.95\%), ethyl-pmethoxycinnamate $(2.13 \%)$ and ethyl cinnamate $(0.79 \%)$. In in vitro microrhizome oil, there were 74 compounds and ethyl p-methoxycinnamate (58.088\%) was detected as most abundant component. Remaining compounds were ethyl cinnamate $(9.16 \%)$, Octahydro$4 \mathrm{a} \quad(2 \mathrm{H})$-naphthalinyl methanol (2.05\%), borneol (1.35\%), pentadecane (1.48\%), $\alpha$-cadinol $(0.73 \%)$ and Retinol $(0.50 \%)$ (Table 2) and minirhizome oil of $K$. galanga containing 15 major compound. In minirhizome oil, ethyl cinnamate $(39.42 \%)$ was the abundant constituent and ethyl p-methoxycinnamate (31.24\%) was also present in an appreciable amount. The other 
compounds recorded in minirhizome oil of $K$. galanga are $\alpha$-pinene (1.16\%), Camphene (1.02), M-Cymene, D-
Limonene (0.9\%), Eucalyptol (5.30), Borneol (3.57\%), Germacrene (1.09\%) and Pentadecane (4.49\%).

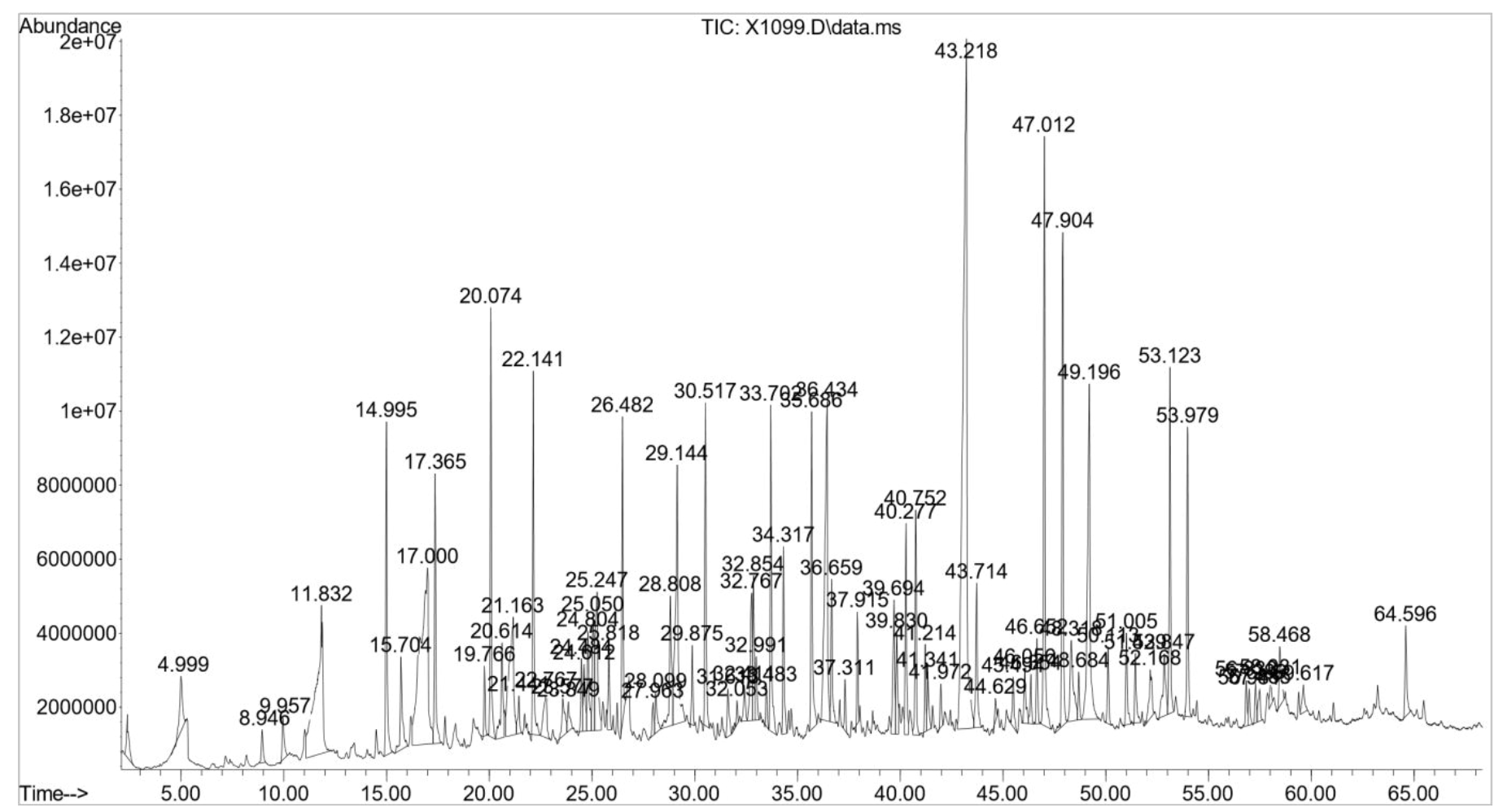

Fig. 1: GC-MS chromatogram of in vivo mother rhizome oil of $K$. galanga

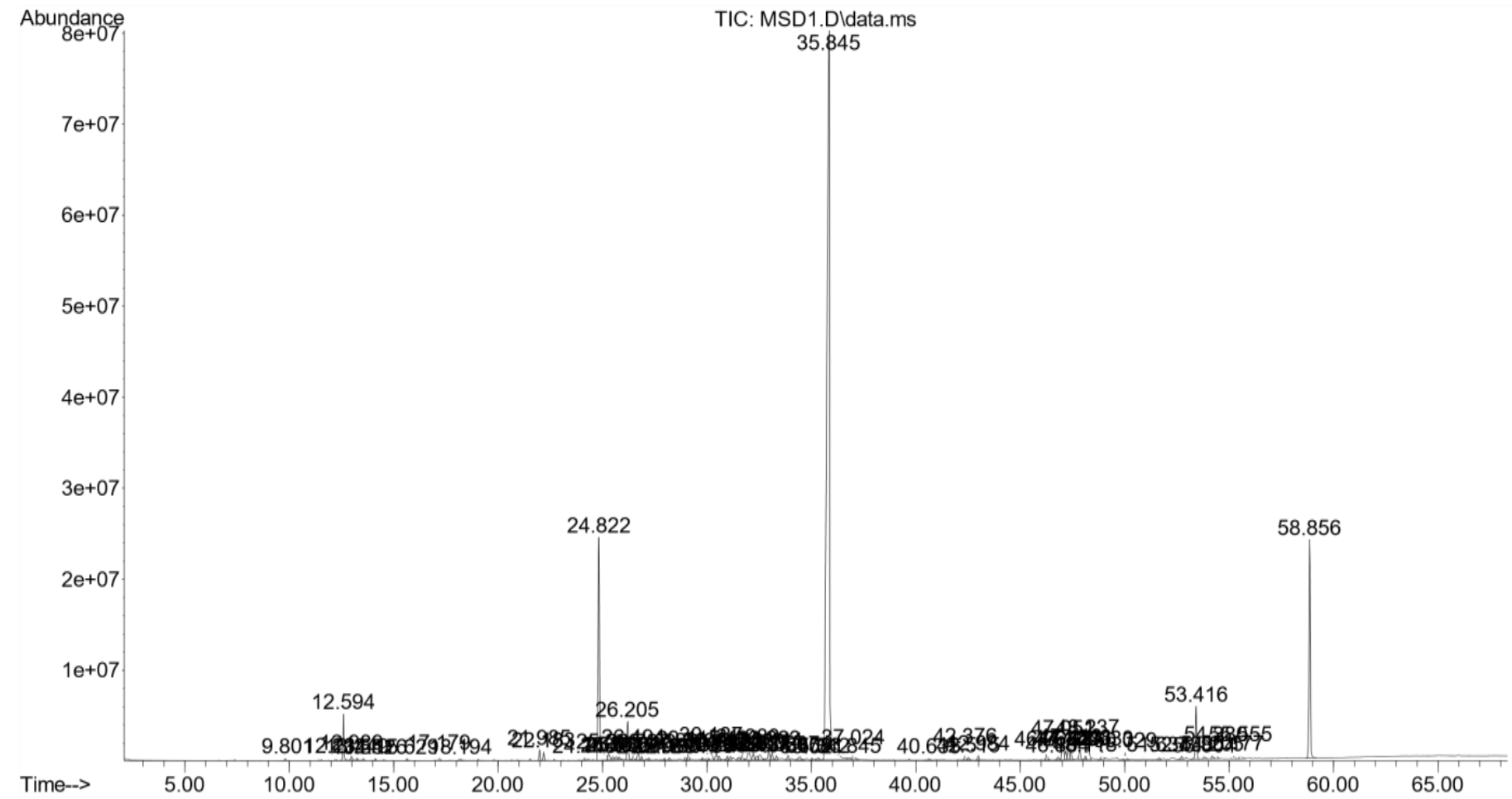

Fig. 2: GC-MS -Chromatogram of in vivo microrhizome oil of $K$. galanga 
Table 1: Essential oil components in in vivo mother rhizome of $K$. galanga

\begin{tabular}{|c|c|c|c|c|c|}
\hline $\begin{array}{c}\text { Peak } \\
\text { number }\end{array}$ & $\begin{array}{l}\text { Retention } \\
\text { time }\end{array}$ & Compound & Common name & $\begin{array}{l}\text { Chemical } \\
\text { formula }\end{array}$ & $\begin{array}{c}\text { Abundance } \\
(\%)\end{array}$ \\
\hline 1 & 2.39 & 1-octanol & Octylalcohol/fatty alcohol & $\mathrm{CH}_{3}\left(\mathrm{CH}_{2}\right)_{7} \mathrm{OH}$ & 0.44 \\
\hline 2 & 4.99 & Nonanal & Nonanaldehyde & $\mathrm{C}_{9} \mathrm{H}_{18} \mathrm{O}$ & 0.69 \\
\hline 5 & 11.83 & Octanoic Acid & Caprylic Acid & $\mathrm{C}_{8} \mathrm{H}_{16} \mathrm{O}_{2}$ & 4.47 \\
\hline 6 & 14.99 & 2-Decenal & Aldehyde & $\mathrm{C}_{10} \mathrm{H}_{18} \mathrm{O}$ & 2.47 \\
\hline 7 & 15.70 & Cyclododecane & Cyclododecane & $\mathrm{C}_{12} \mathrm{H}_{24}$ & 0.90 \\
\hline 8 & 17.00 & n-Decanoic acid & Capric acid & $\mathrm{CH}_{3}\left(\mathrm{CH}_{2}\right)_{8} \mathrm{COOH}$ & 6.45 \\
\hline 9 & 17.36 & Tridecanal & Saturated fatty acid & $\mathrm{C}_{13} \mathrm{H}_{26} \mathrm{O}$ & 1.72 \\
\hline 11 & 20.07 & 2-Dodecenal & Unsaturated fatty aldehyde & $\mathrm{C}_{12} \mathrm{H}_{22} \mathrm{O}$ & 2.47 \\
\hline 12 & 20.61 & 1-Undecanol & Fatty alcohol & $\mathrm{C}_{11} \mathrm{H}_{24} \mathrm{O}$ & 0.92 \\
\hline 13 & 21.16 & n-Decanoic acid & Capric acid & $\mathrm{CH}_{3}\left(\mathrm{CH}_{2}\right)_{8} \mathrm{COOH}$ & 2.51 \\
\hline 15 & 22.14 & Cyclododecane & Cycloalkane & $\mathrm{C}_{10} \mathrm{H}_{20}$ & 2.02 \\
\hline 16 & 22.77 & 2-decenoic acid & Monosaturated fatty acid & $\mathrm{C}_{10} \mathrm{H}_{18} \mathrm{O}_{2}$ & 0.68 \\
\hline 19 & 24.48 & 2(3H) Furanone- & §-Decalactone & $\mathrm{C}_{10} \mathrm{H}_{18} \mathrm{O}_{2}$ & 0.43 \\
\hline 20 & 24.61 & 2-Dodecenal & Unsaturated fatty aldehyde & $\mathrm{C}_{12} \mathrm{H}_{22} \mathrm{O}$ & 0.56 \\
\hline 21 & 24.80 & $\begin{array}{l}\text { 2-propenoic acid ,3- } \\
\text { phenyl,ethyl ester }\end{array}$ & Ethyl cinnamate & $\mathrm{C}_{11} \mathrm{H}_{12} \mathrm{O}_{2}$ & 0.79 \\
\hline 22 & 25.05 & n-Tridecan-1-ol & Tridecanol & $\mathrm{C}_{13} \mathrm{H}_{28} \mathrm{O}$ & 0.99 \\
\hline 23 & 25.25 & Undecanoic acid & Undecylic acid (carboxylic acid) & $\mathrm{C}_{11} \mathrm{H}_{22} \mathrm{O}_{2}$ & 1.77 \\
\hline 25 & 26.48 & Tetradecanal & Myristyl aldehyde(myristic acid) & $\mathrm{C}_{14} \mathrm{H}_{28} \mathrm{O}$ & 1.63 \\
\hline 28 & 28.81 & $\begin{array}{l}\text { 2(3H)Furanone, 5-heptyl } \\
\text { dihydro- }\end{array}$ & $\mathrm{\gamma}$-Undecalatone & $\mathrm{C}_{11} \mathrm{H}_{20} \mathrm{O} 2$ & 1.32 \\
\hline 29 & 29.14 & Dodecanoic acid & $\begin{array}{c}\text { Lauric acid } \\
\end{array}$ & $\mathrm{C}_{12} \mathrm{H}_{24} \mathrm{O}_{2}$ & 3.08 \\
\hline 31 & 30.52 & Tetradecanal & Myristyl aldehyde(myristic acid) & $\mathrm{C}_{14} \mathrm{H}_{28} \mathrm{O}$ & 1.97 \\
\hline 35 & 32.77 & Tridecanoic acid & $\begin{array}{l}\text { Tridecylic acid(saturated fatty } \\
\text { acid) }\end{array}$ & $\mathrm{C}_{13} \mathrm{H}_{26} \mathrm{O}_{2}$ & 1.17 \\
\hline 36 & 32.85 & $\begin{array}{l}\text { 2(3H)Furanone, 5-heptyl } \\
\text { dihydro }\end{array}$ & $\mathrm{\gamma}$-Undecalatone & $\mathrm{C}_{11} \mathrm{H}_{20} \mathrm{O} 2$ & 0.92 \\
\hline 39 & 33.70 & 2-pentadecanone & Methyl tridecyl ketone & $\mathrm{C}_{15} \mathrm{H}_{30} \mathrm{O}$ & 2.09 \\
\hline 40 & 34.32 & Hexadecanl & Palmityol & $\mathrm{C}_{16} \mathrm{H}_{32} \mathrm{O}$ & 1.14 \\
\hline 41 & 35.69 & $\begin{array}{l}\text { 2-Propenoic acid,3(4- } \\
\text { methoxyphenyl)-ethyl ester }\end{array}$ & Ethyl p-methoxycinnamate & $\mathrm{C}_{12} \mathrm{H}_{14} \mathrm{O}_{3}$ & 2.13 \\
\hline 42 & 36.43 & Tetradecanoic acid & Myristic acid & $\mathrm{C}_{14} \mathrm{H}_{28} \mathrm{O}_{2}$ & 3.92 \\
\hline 43 & 36.66 & $\begin{array}{c}\text { 1-Decanol, 10[(tetrahydro- } \\
\text { 2H-pyran-2-yl)oxy]- }\end{array}$ & $\begin{array}{l}\text { 1-Decanol, } 10 \text { [(tetrahydro-2H- } \\
\text { pyran-2-yl)oxy]- }\end{array}$ & $\mathrm{C}_{15} \mathrm{H}_{30} \mathrm{O}_{3}$ & 0.98 \\
\hline 46 & 39.69 & Pentadecanoic acid & $\begin{array}{l}\text { Pentadecanoic acid(saturated } \\
\text { fatty acid) }\end{array}$ & $\mathrm{C}_{15} \mathrm{H}_{30} \mathrm{O}_{2}$ & 1.08 \\
\hline 48 & 40.28 & $\begin{array}{l}\text { Sulfurous acid, hexyl undecyl } \\
\text { ester }\end{array}$ & Hexyl undecyl sulphite & $\mathrm{C}_{17} \mathrm{H}_{36} \mathrm{O}_{3} \mathrm{~S}$ & 1.35 \\
\hline 49 & 40.75 & 2-Heptadecanone & Methyl pentadecyl ketone & $\mathrm{C}_{17} \mathrm{H}_{34} \mathrm{O}$ & 1.37 \\
\hline 53 & 43.22 & n-Hexadecanoic acid & Palmitic acid & $\mathrm{C}_{16} \mathrm{H}_{32} \mathrm{O}_{2}$ & 12.22 \\
\hline 54 & 43.71 & $\begin{array}{l}\text { 2-(6-bromohexyloxy) } \\
\text { tetrahydro-2H pyran }\end{array}$ & $\begin{array}{l}\text { 2-(6-bromohexyloxy) } \\
\text { tetrahydro-2H pyran }\end{array}$ & $\mathrm{C}_{11} \mathrm{H}_{21} \mathrm{BrO}_{2}$ & 1.09 \\
\hline 60 & 47.01 & $\begin{array}{c}\text { 2(3H)-Furanone, } 5- \\
\text { dodecyldihydro- }\end{array}$ & Gamma palmitolactone & $\mathrm{C}_{16} \mathrm{H}_{30} \mathrm{O}_{2}$ & 3.92 \\
\hline 61 & 47.90 & $\begin{array}{c}\text { RH-Pyran-2-one,tetrahydro- } \\
\text { 6-nonyl } \\
\end{array}$ & $\delta$-tetradecalactone & $\mathrm{C}_{14} \mathrm{H}_{26} \mathrm{O}_{2}$ & 3.26 \\
\hline 62 & 48.38 & Oleic acid & Oleic acid & $\mathrm{C}_{18} \mathrm{H}_{34} \mathrm{O}_{2}$ & 1.19 \\
\hline 64 & 49.19 & Octadecanoic acid & Stearic acid & $\mathrm{C}_{18} \mathrm{H}_{36} \mathrm{O}_{2}$ & 3.95 \\
\hline 69 & 52.85 & 6-Octadecenoic acid(z)- & Petroselinic acid & $\mathrm{C}_{18} \mathrm{H}_{34} \mathrm{O}_{2}$ & 0.82 \\
\hline 70 & 53.12 & $\begin{array}{l}\text { 2(3H)-Furanone, dihydro-5- } \\
\text { tetradecyl }\end{array}$ & Y-Stearolactone & $\mathrm{C}_{18} \mathrm{H}_{34} \mathrm{O}_{2}$ & 2.11 \\
\hline 71 & 53.98 & $\begin{array}{l}\text { 2sH-Pyran-2-one, tetrahydro- } \\
\text { 6-tridecyl }\end{array}$ & $\delta$-Octadelactone & $\mathrm{C}_{18} \mathrm{H}_{34} \mathrm{O}_{2}$ & 1.80 \\
\hline 75 & 57.49 & Pentadecane & Pentadecane & $\mathrm{C}_{15} \mathrm{H}_{32}$ & 0.32 \\
\hline
\end{tabular}


Table 2: Major compounds in in vivo mother rhizomes and their activities

\begin{tabular}{cl}
\hline Compound & \multicolumn{1}{c}{ Bioactivity } \\
\hline Palmitic acid & Antifungal, antibacterial, antiinflammatory, production of cosmetics, soaps, etc. [29]. \\
\hline Capric acid & Antimicrobial, larvicidal, cholesterol dissolving agent, manufacture of perfumes [30]. \\
\hline Caprylic Acid & Antifungal, antibacterial [20], Cleansing agent, perfuming agent \\
\hline Lauric acid & Antimicrobial, used in alcoholic beverages, flavour and fragrance agent, \\
\hline Stearic acid & Anticancerous, production of cooking oil, soap cosmetics, soap production [36]. \\
\hline Myristic acid & Anti-microbial, Improving HDL [37], making cosmetics, fragrance ingredient \\
\hline Gamma palmitolactone & Antimicrobial activity, flavouring agent \\
\hline -tetradecalactone & Flavour ingradient \\
\hline Ethyl p- & Antiinflammatory [15], antifungal [38], larvicidal [39], analgesic, anti-iv, TB molecule \\
methoxycinnamate & [40], Cytototoxic pro and pro-apoptotic properties, Anticancer [14] \\
\hline Ethyl cinnamate & Anticancer [41], antimicrobial, anti-oxidative [42], Mosquito repellent activity, \\
\hline Pentadecane & Vasorelaxant activity [22], Larvicidal activity [43]. \\
\hline
\end{tabular}

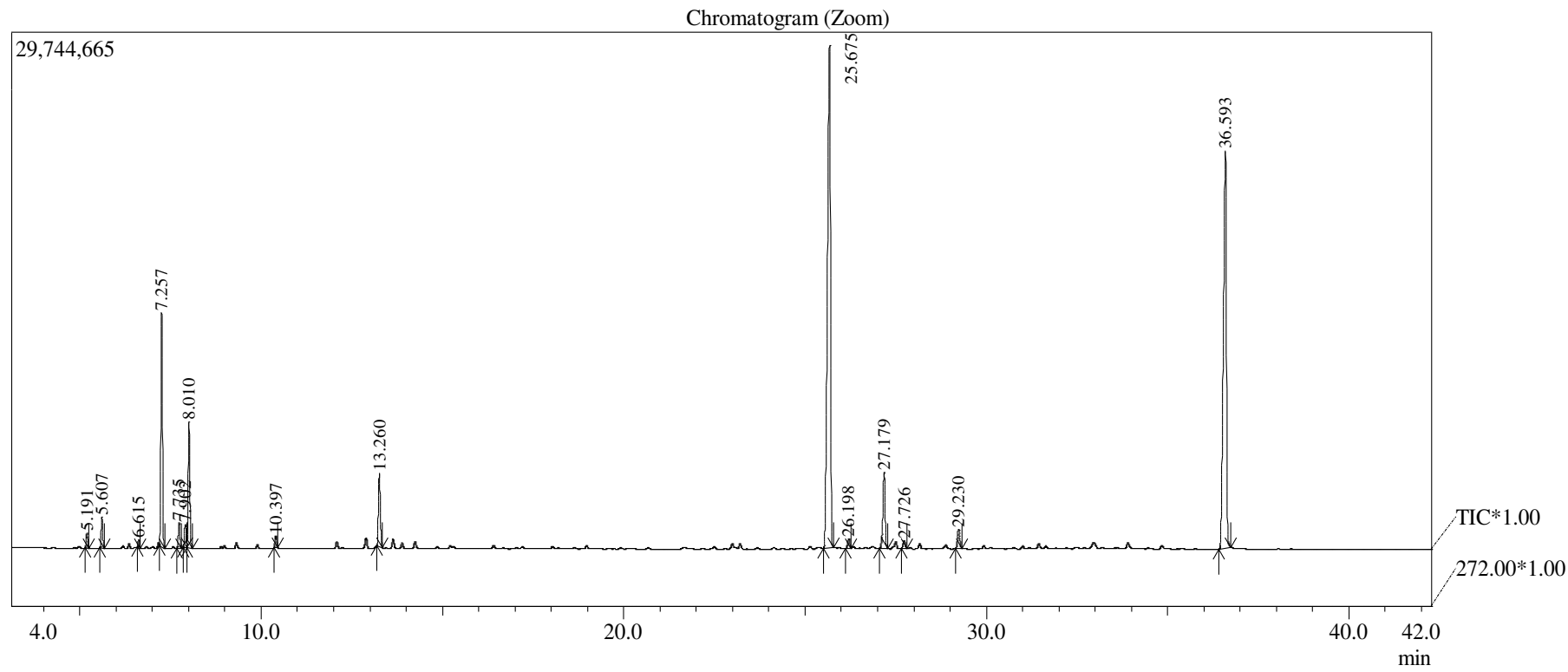

Fig. 3: GC-MS -Chromatogram of in vivo minirhizome oil of K.galanga

\subsection{Major compounds in in vivo rhizome oil and their bioactivities}

Most of the compounds found in the samples analysed here have been reported to exhibit significant biological activities. Some of the major compounds in in vivo rhizome oil and their bioactivities were mentioned in Table 2. According to scientists [28] monoterpenes and sesquiterpenes were found in the essential oil of $K$. galanga rhizomes which have contributed the flavour and fragrance properties to the oil. Among the 41 compound analysed in in vivo rhizome oil, the highest percentage of abundance was with palmitic acid (12.22), a saturated fatty acid which is having many medicinal properties like antifungal, antibacterial and also used for the production soaps and cosmetics [29]. Capric acid $(6.45 \%)$, was another fatty acid component present in in vivo rhizome essential oil of $K$. galanga. This is also a saturated fatty acid with anti inflammatory and antibacterial properties [30]. These fatty acids were also present in many other zingiberaceous members. For example, $22.18 \%$ palmitic acid and $3.81 \%$ of capric acid was reported in Z. officianale [31].

Caprylic acid, one of the compounds present in in vivo rhizome oil is used commercially in the production of esters used in perfumery and also in the manufacture of dyes. Caprylic acid has been studied as part of a ketogenic diet to treat children with intractable epilepsy [32] and is currently being researched as a treatment for essential tremor [33]. Its presence is also reported in Zingiberaceae members like Curcuma longa [34] and Z. officianale [31]. Lauric acid, Stearic acid and myristic acids are also present in in vivo rhizome oil. 
Quantification of these components were previously done [31] in Z. officianale (Lauric acid 8.34\%, Stearic acid $3.45 \%$, myristic acid 5.85\%) and in Heliotropium bacciferum [35] (Stearic acid $1.74 \%$ and myristic acid $0.20 \%$ ). Ethyl p-methoxycinnamate and ethyl cinnamate were the most active compounds in $K$. galanga based on previous studies [5]. However, these compounds were also analysed in mother rhizome oil samples in least amount, but interestingly, the quantity of these medicinally important compounds were in enhanced levels in the microrhizome and minirhizome oil samples.

\subsection{Major compounds in in vitro microrhizomes and their bioactivities}

Bioactive compounds present in in vitro microrhizome oil of $K$. galanga were explained in the Table 3. Major compounds present in in vitro rhizome oil and their bioactivities were mentioned in Table 4. The present study revealed that, there is great variation in the case of chemical constituents in in vivo rhizome and in vitro microrhizome. The percentage of ethyl pmethoxycinnamate and ethyl cinnamate was comparatively high in in vitro microrhizome than in vivo rhizome. In in vitro rhizome oil, ethyl pmethoxycinnamate $(58.088 \%)$ was the predominant compound. The major compounds present viz. ethyl cinnamate and ethyl-p-methoxycinnamate are esters which contribute the nematicidal, anticancer, antituberculosis, anti-inflammatory, antifungal and larvicidal properties [39] to the oil. It has been used for the treatment of pain and inflammation and this compound also exhibits inhibitory activity against proliferation of tumor cell in the specimen of mouse epidermis and extent of papilloma [45]. Based on the previous reports [10] rhizome oil of $K$. galanga contain $46.81 \%$ while, the in vitro whole plant oil contain $51.23 \%$ of ethyl p- methoxycinnamate. Here in our sample i.e., in vitro microrhizome essential oil contain predominantly high amount of (58.088) ethyl pmethixycinnamate. Another active compound present was ethyl cinnamate $(9.78 \%)$ having many reported medicinal properties like anticancer [41], antimicrobial, anti-oxidative [42], mosquito repellent and vasorelaxant activity [22]. Borneol (1.349\%) was seen in in vitro rhizome oil, while $2.85 \%$ borneol was detected in dried conventional rhizome samples of $K$. galanga [13] and $1.0-2.4 \%$ borneol was reported in $K$. galanga by [46]. It is a terpene derivative having many medicinal properties like, anticoagulant and antithrombotic activities [47] along with antihypertensive and antioxidant activities [48]. Pentadecane is one of the active compound reported in $K$. galanga and $1.48 \%$ of pentadecane was present in in vitro microrhizome essential oil. According to scientists [10], the in vitro whole plant rhizome oil contains $3.69 \%$ pentadecane and in conventional rhizome oil, it was $5.81 \%$. Humulene epoxide 2, retinol, caryophyllene, $\alpha$-cadinol are the other active compounds present in in vitro rhizome oil. $\alpha$-cadinol is a cadinane sesquiterpenoid having antifungal activity [49] and it was previously reported in $K$. galanga by [10], it was $0.11 \%$ in rhizome oil and $0.06 \%$ in vitro whole plant oil and in our sample $0.71 \%$ of cadinol is recorded. Caryophyllene and humulene epoxide 2 were also sesquiterpenoids, reported earlier in $K$. galanga [50] and $0.41 \%$ of caryophyllene and $0.61 \%$ humulene epoxide were present in the microrhizome oil of $K$. galanga. Humulene is also known as $\alpha$-caryophyllene and it is having many therapeutical and pharmacological applications [51]. Retinol is also present in in vitro microrhizome oil of $K$. galanga, it is also called vitamin $\mathrm{A}_{1}$; vitamin in the vitamin A family and used as a dietary supplement. As a supplement it is used to treat and prevent vitamin A deficiency [52].

\subsection{Major compounds in minirhizomes and their activities}

GCMS analysis of $K$. galanga minirhizome essential oil, revealed the presence of 15 major compounds. Among these, ethyl p-methoxycinnamate (31.24\%) and ethyl cinnamate $(39.42 \%)$ were the predominant ones. Eucalyptol (5.30\%) a monoterpenoid, was one of the compound present and its presence already reported in other zingiberaceae species like Hedychium flavescens (15.3\%) [54] and 2.12\% in K. galanga [55]. Borneol is a terpene derivative with many medicinal properties like insect repellent, traditional Chinese medicine, skin tonic, sedative and antiplasmodic, stimulating the production of gastric juices, improve circulation, treat bronchitis, reduce swellings, relives stress and has analgesic potential [53]. The minirhizomes recorded $3.5 \%$ of borneol and the same amount was reported earlier [46], while the amount was lesser (1.03\%) [55]. Camphene $(1.36 \%), \quad \alpha$-pinene $(0.52 \%)$, Carene (9.52\%), pentadecane (4.49\%),germacrene (1.09\%) were the other constituents present minirhizome oil of K. galanga. 
Preetha et al., J Adv Sci Res, 2022; 13(1): 188-199

Table 3: Essential oil components in in vitro microrhizome of $K$. galanga

\begin{tabular}{|c|c|c|c|c|c|}
\hline $\begin{array}{c}\text { Peak } \\
\text { number }\end{array}$ & $\begin{array}{l}\text { Retention } \\
\text { time }\end{array}$ & Compound & Common name & $\begin{array}{l}\text { Chemical } \\
\text { formula }\end{array}$ & $\begin{array}{c}\text { Abundance } \\
(\%)\end{array}$ \\
\hline 3 & 12.23 & Borneol & Borneol & $\mathrm{C}_{10} \mathrm{H}_{18} \mathrm{O}$ & 1.35 \\
\hline 4 & 12.99 & $\begin{array}{l}\text { Benzene methanol } \alpha, \alpha, 4- \\
\text { trimethyl }\end{array}$ & P-Cymenol & $\mathrm{C}_{10} \mathrm{H}_{14} \mathrm{O}$ & 0.22 \\
\hline 9 & 17.18 & Bornyl acetate & Acetate ester of borneol & $\mathrm{C}_{12} \mathrm{H}_{20} \mathrm{O}_{2}$ & 0.20 \\
\hline 14 & 24.82 & $\begin{array}{l}\text { 2-propenoic acid ,3- } \\
\text { phenyl,ethyl ester }\end{array}$ & Ethyl cinnamate & $\mathrm{C} 11 \mathrm{H} 12 \mathrm{O}_{2}$ & 9.77 \\
\hline 19 & 26.20 & Pentadecane & Pentadecane & $\mathrm{C}_{15} \mathrm{H}_{32}$ & 1.48 \\
\hline 20 & 26.49 & $\begin{array}{l}\text { Naphthalene ,1,2,4a,5,6,8a- } \\
\text { hexahydro-4,7-dimethyl-1- } \\
\text { (1-methylethyl)- }\end{array}$ & $\alpha$-amorphene & $\mathrm{C}_{15} \mathrm{H}_{24}$ & 0.38 \\
\hline 21 & 26.71 & $\begin{array}{l}\text { Naphthalene ,1,2,3,5,6,8a- } \\
\text { hexahydro-4,7-dimethyl-1- } \\
\text { (1-methylethyl)-,(1s-cis)- }\end{array}$ & $\alpha$-Cadinine & $\mathrm{C}_{15} \mathrm{H}_{24}$ & 0.36 \\
\hline 27 & 29.12 & Caryophyllene oxide & Caryophyllene oxide & $\mathrm{C}_{15} \mathrm{H}_{24} \mathrm{O}$ & 0.34 \\
\hline 30 & 30.19 & $\begin{array}{c}\text { 12-Oxybicyclo[9.1.0] } \\
\text { dodeca-3,7diene, } 1,5,5,8- \\
\text { tetramethyl }\end{array}$ & Humulene epoxide 2 & $\mathrm{C}_{15} \mathrm{H}_{24} \mathrm{O}$ & 0.63 \\
\hline 31 & 30.45 & $\begin{array}{l}\text { Dihydro-cis-alpha- } \\
\text { copaene-8-ol }\end{array}$ & & $\mathrm{C}_{15} \mathrm{H}_{26} \mathrm{O}$ & 0.41 \\
\hline 37 & 31.98 & $\alpha$-Cadinol & Cadinanesesquiterpenoid & $\mathrm{C}_{15} \mathrm{H}_{26} \mathrm{O}$ & 0.73 \\
\hline 38 & 32.22 & $\begin{array}{l}\text { Cyclohexane,6-ethenyl-6- } \\
\text { methyl-1-(1-methyl)-3-(1- } \\
\text { methylethylidene-(s)- }\end{array}$ & Alpha elemene & $\mathrm{C}_{15} \mathrm{H}_{24}$ & 0.33 \\
\hline 40 & 32.52 & Caryophyllene & Bicyclic sesquiterpene & $\mathrm{C}_{15} \mathrm{H}_{24}$ & 0.41 \\
\hline 41 & 32.96 & 1,E-8,Z-10-Tetradecatriene & & $\mathrm{C}_{16} \mathrm{H}_{28}$ & 0.51 \\
\hline 42 & 33.11 & Aromadendrene, dehydro & Dehydromadendrene & $\mathrm{C}_{15} \mathrm{H}_{22}$ & 0.33 \\
\hline 45 & 34.46 & (E)-3(10)-Caren-4-ol & & $\mathrm{C}_{10} \mathrm{H}_{16} \mathrm{O}$ & 0.28 \\
\hline 48 & 35.85 & $\begin{array}{l}\text { 2-Propenoic acid,3(4- } \\
\text { methoxyphenyl)-ethyl ester }\end{array}$ & $\begin{array}{c}\text { Ethyl p- } \\
\text { methoxycinnamate }\end{array}$ & $\mathrm{C}_{12} \mathrm{H}_{14} \mathrm{O}_{3}$ & 58.09 \\
\hline 52 & 42.38 & $\begin{array}{c}\text { 1-Buten-1-ol,2-methyl-4- } \\
\text { (2,6,6-trimethyl-1- } \\
\text { cyclohexen0.-1-yl)- }\end{array}$ & & $\mathrm{C}_{13} \mathrm{H}_{22} \mathrm{O}$ & 0.43 \\
\hline 55 & 46.27 & $\begin{array}{c}\text { Benzene,1,1-[1- } \\
\text { (methylthio)ethylidene]bis- }\end{array}$ & $\begin{array}{l}\text { 1-Methylsulfanyl-1- } \\
\text { (phenylethyl)benzene }\end{array}$ & $\mathrm{C}_{15} \mathrm{H}_{16} \mathrm{~S}$ & 0.35 \\
\hline 57 & 47.05 & $\begin{array}{c}\text { (z)-4-Chloro-2,3-dimethyl- } \\
\text { 1,3-hexadiene }\end{array}$ & & $\mathrm{C}_{8} \mathrm{H}_{13} \mathrm{Cl}$ & 1.18 \\
\hline 58 & 47.18 & Anthracene,9-propyl- & 9-Propylanthracene & $\mathrm{C}_{17} \mathrm{H}_{16}$ & 0.37 \\
\hline 59 & 47.32 & Retinol & Retinol & $\mathrm{C}_{20} \mathrm{H}_{30} \mathrm{O}$ & 0.50 \\
\hline 60 & 47.41 & $\begin{array}{c}\text { 2,4-Bis(chloromethyl) } \\
\text { mesitylene } \\
\end{array}$ & & $\mathrm{C}_{11} \mathrm{H}_{14} \mathrm{Cl}_{2}$ & 0.49 \\
\hline 61 & 47.85 & $\begin{array}{l}\text { 3-Pyridinemethanol,5- } \\
\text { hydroxy-4,6-dimethyl- }\end{array}$ & & $\mathrm{C}_{8} \mathrm{H}_{11} \mathrm{NO}_{2}$ & 0.44 \\
\hline 68 & 53.42 & $\begin{array}{l}4 \mathrm{a}(2 \mathrm{H})-\mathrm{Naphthaleneme-} \\
\text { thanol, octahydro }\end{array}$ & & $\mathrm{C}_{11} \mathrm{H}_{20} \mathrm{O}$ & 2.05 \\
\hline 71 & 54.38 & $\begin{array}{l}\text { 1-Ethyl-3-propyl-5- } \\
\text { (propene-1-yl)adamantine }\end{array}$ & & $\mathrm{C}_{18} \mathrm{H}_{30}$ & 0.51 \\
\hline 72 & 55.18 & Vitamin A acetate & Vitamin A acetate & $\mathrm{C}_{22} \mathrm{H}_{32} \mathrm{O}_{2}$ & 0.25 \\
\hline
\end{tabular}


Table 4: Major compounds in in vitro rhizomes and their activities

\section{Compound}

\begin{tabular}{|c|c|}
\hline Compound & Bioactivity \\
\hline Ethyl p-methoxycinnamate & $\begin{array}{l}\text { Anti-inflammatory [15], antifungal [38]. } \\
\text { larvicidal [39] analgesic , anti-HIV, TB molecule [40], Cytototoxic pro and pro- } \\
\text { apoptotic properties, Anticancer [14]. }\end{array}$ \\
\hline Ethyl cinnamate & $\begin{array}{l}\text { Anticancer [41], antimicrobial, anti-oxidative [42], Mosquito repellent activity, } \\
\text { Vaso-relaxant activity [22], Larvicidal activity [43]. }\end{array}$ \\
\hline Borneol & $\begin{array}{l}\text { Insect repellent, traditional Chinese medicine, skin tonic, sedative and } \\
\text { antiplasmodic, stimulating the production of gastric juices, improve circulation, } \\
\text { treat bronchitis, reduce swellings, relives stress, Analgesic potential [53], } \\
\text { Anticoagulant and antithrombotic activities [47], Antihypertensive and anti-oxidant } \\
\text { [48] }\end{array}$ \\
\hline Pentadecane & Antibacterial [44]. \\
\hline$\alpha$-Cadinol & Antifungal [49], Hepatoprotective \\
\hline Humulene epoxide 2 & Used in alcoholic bevarages, present in many food items. \\
\hline Retinol & $\begin{array}{l}\text { Used to treat and prevent Vitamin A deficiency, stimulate blood flow and collagen } \\
\text { production. }\end{array}$ \\
\hline Caryophyllene & $\begin{array}{l}\text { Inhibit cancer cell growth, reducing stress, slowing the growth of bacteria, } \\
\text { reducing chronic inflammation. }\end{array}$ \\
\hline
\end{tabular}

Table 5: Essential oil components in minirhizome of $K$. galanga

\begin{tabular}{|c|c|c|c|c|c|}
\hline $\begin{array}{c}\text { Peak } \\
\text { number }\end{array}$ & $\begin{array}{l}\text { Retention } \\
\text { time }\end{array}$ & Compound & Common name & $\begin{array}{l}\text { Chemical } \\
\text { formula }\end{array}$ & $\begin{array}{c}\text { Abundance } \\
(\%)\end{array}$ \\
\hline 1 & 5.1 & $\begin{array}{c}\text { Bicyclo[3.1.1]Hept-2- Ene,2,6,6- } \\
\text { trimethyl }\end{array}$ & $\alpha$-pinene & $\mathrm{C}_{10} \mathrm{H}_{16}$ & 0.52 \\
\hline 2 & 5.61 & $\begin{array}{c}\text { Bicyclo[2.2.1]Heptane,2,2- } \\
\text { Dimethyl-3-Methyl }\end{array}$ & Camphene & $\mathrm{C}_{10} \mathrm{H}_{16}$ & 1.16 \\
\hline 3 & 6.62 & $\begin{array}{l}\text { 1,6- Octadiene, 7-Methyl-3- } \\
\text { Methylene }\end{array}$ & Myrcene & $\mathrm{C}_{10} \mathrm{H}_{16}$ & 0.28 \\
\hline 4 & 7.26 & Bicyclo[4.1.0]Hept-3,7,7-Trimethyl & $(+)$-2Carene & $\mathrm{C}_{10} \mathrm{H}_{16}$ & 9.52 \\
\hline 5 & 7.74 & Benzene,Methyl(1-Methylethyl)- & M-Cymene & $\mathrm{C}_{10} \mathrm{H}_{14}$ & 1.02 \\
\hline 6 & 7.90 & D-Limonene & D-Limonene & $\mathrm{C}_{10} \mathrm{H}_{16}$ & 0.9 \\
\hline 7 & 8.01 & $\begin{array}{c}\text { 2-Oxabicyclo[2.2.2] Octane, 1,3,3- } \\
\text { Trimethyl }\end{array}$ & Eucalyptol & $\mathrm{C}_{10} \mathrm{H}_{18} \mathrm{O}$ & 5.30 \\
\hline 8 & 10.39 & (5E,8E)-5,8,10-Undecatrien-3-ol & & $\mathrm{C}_{11} \mathrm{H}_{18} \mathrm{O}$ & 0.50 \\
\hline 9 & 13.26 & $\begin{array}{c}\text { Bycyclo[2,2.1]Heptan-2-ol,1,7,7- } \\
\text { Trimethyl }\end{array}$ & Borneol & $\mathrm{C}_{11} \mathrm{H}_{12} \mathrm{O}$ & 3.57 \\
\hline 10 & 25.68 & $\begin{array}{l}\text { 2-propenoic acid ,3-phenyl, } \\
\text { ethyl ester }\end{array}$ & Ethyl cinnamate & $\mathrm{C}_{11} \mathrm{H}_{12} \mathrm{O}_{2}$ & 39.42 \\
\hline 11 & 26.19 & $\begin{array}{l}\text { 1,6 Cyclodecadiene, 1-Methyl-5- } \\
\text { Methylene }\end{array}$ & Germacrene & & 0.50 \\
\hline 12 & 27.18 & Pentadecane & Pentadecane & $\mathrm{C}_{15} \mathrm{H}_{32}$ & 4.49 \\
\hline 13 & 27.73 & $\begin{array}{l}\text { Naphthalene, 1,2,3,5.6.8A- } \\
\text { Hexahydro-47 Dimethyl }\end{array}$ & & $\mathrm{C}_{15} \mathrm{H}_{24}$ & 0.42 \\
\hline 14 & 29.23 & Germacrene B & Germacrene & $\mathrm{C}_{15} \mathrm{H}_{24}$ & 1.09 \\
\hline 15 & 36.59 & Ethyl-p- methoxycinnamate & $\begin{array}{c}\text { Ethyl-p- } \\
\text { methoxycinnamate }\end{array}$ & $\mathrm{C}_{11} \mathrm{H}_{14} \mathrm{O}_{3}$ & 31.24 \\
\hline
\end{tabular}


3.4. Comparison of major compounds in micro, mini and in vivo mother rhizomes

Common compounds present in the three essential oil rhizome samples i.e., in vitro microrhizome oil, minirhizome oil and in vivo mother rhizome oil and their percentage of abundance were plotted in Fig. 4. Ethyl p-methoxycinnamate, ethyl cinnamate, pentadecane were present in the three samples while borneol was recorded in micro and minirhizome oil. These three are the most active compounds in $K$. galanga. In our study we discussed about the comparison of three rhizome samples of $K$. galanga. Quantification of essential oil components from different part of $K$. galanga like leaves, rhizome, whole pants were carried out previously $[7,10,46]$. But, no studies yet were found regarding the esssential oil composition in microrhizome and minirhizome oil. Ethyl pmethoxycinnamate and ethyl cinnamate are found to be most vital constituents responsible for the pharmacological activities of $K$. galanga. Among the three samples analysed here, in vitro micro rhizome oil possess more amount of ethtyl p-methoxycinnamate i.e., $58.088 \%$ and is more or less similar to that of the report [10]. It's amount was $31.24 \%$ in minirhizome oil, while it was $2.132 \%$ in in vivo mother rhizome oil.

Table 6: Major compounds in minirhizomes and their activities

\begin{tabular}{cl}
\hline Compounds & \multicolumn{1}{c}{ Bioactivity } \\
\hline$\alpha$-pinene & Anti-inflammatory and anti-carcinogenic effects [56]; larvicidal activity [57]. \\
\hline Camphene & Antifangal, antibacterial [58]. \\
\hline+ )-2Carene & Air freshners, cosmetics \\
\hline Eucalyptol & Insecicidal. Insect repellent, Cough supressent[59] \\
\hline & $\begin{array}{l}\text { Insect repellent, traditional Chinese medicine, skin tonic, sedative and } \\
\text { antiplasmodic, stimulating the production of gastric juices, improve circulation, }\end{array}$ \\
Borneol & treat bronchitis, reduce swellings, relives stress, Analgesic potential [53] \\
& Anticoagulant and antithrombotic activities [47], Antihypertensive and anti-oxidant \\
& ([48] \\
\hline Ethyl cinnamate & Anticance[r41], antimicrobial, anti-oxidative [42], Mosquito repellent activity, \\
\hline Pentadecane & Antibacterial [44] \\
\hline Germacrene & Anti-inflammatory, anti-bacterial, antifungal. \\
\hline \multirow{2}{*}{ Ethyl-p- methoxycinnamate } & Anti-inflammatory [15]antifungal [38] larvicidal [39] analgesic,anti-HIV, TB \\
& molecule [40], Cytototoxic pro and pro-apoptotic properties, Anticancer [14] \\
\hline
\end{tabular}

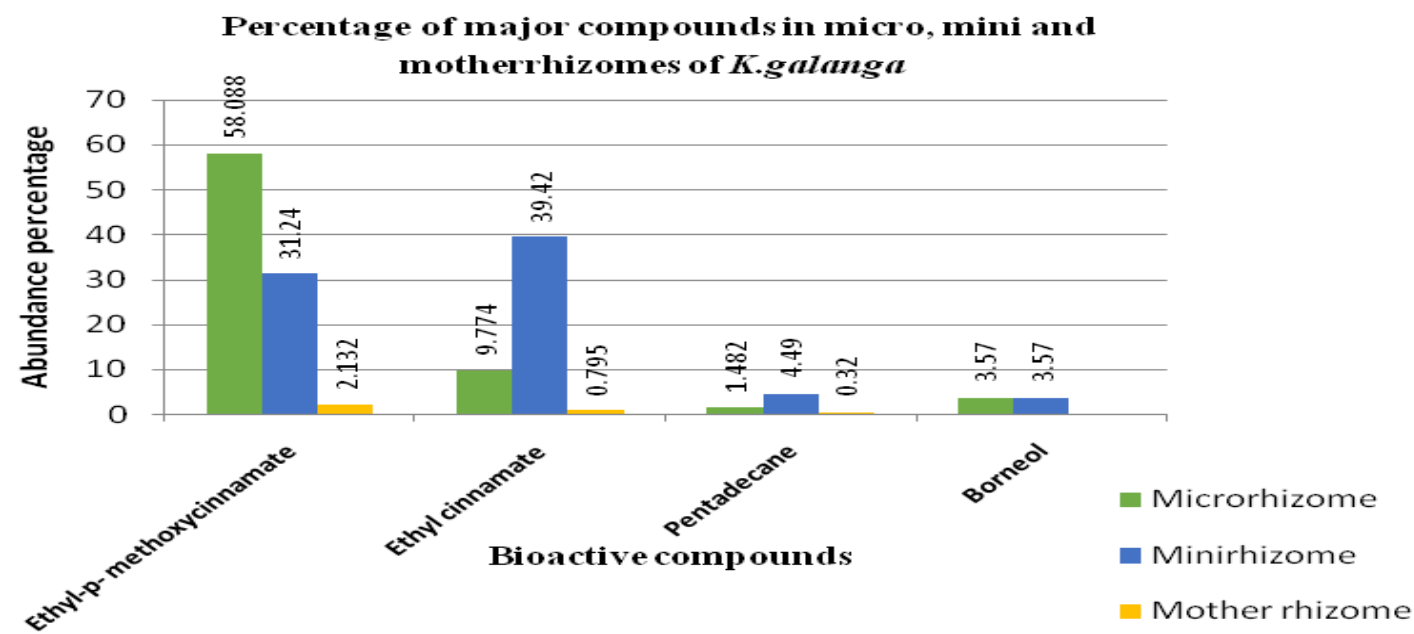

Fig. 4: Comparison of major compounds in K. galanga rhizome samples 
The amount ethyl p- methoxycinnamate was very high in microrhizome and minirhizome oil as compared to the report [46] as well as with the findings [55] who previously proposed the amount of ethyl pmethoxycinnamate as $25.96 \%$ in essential oil $K$. galanga. Another potential component ethlyl cinnamate was 9.21 $\%$ in microrhizome oil and it increased to $39.42 \%$ in minirhizome oil. Earlier reports suggest $24.8 \%$ of ethy cinnamate in rhizome oil and $19.23 \%$ in in vitro whole plants of $K$. galanga [10]. The amount of the same constituent in minirhizome oil in our analysis was much higher than that of earlier record of $11.5-26.6 \%$ [46]. According to scientists [17] the amount of ethyl cinnamate in conventional rhizome of $K$. galanga was $9.69 \%$ and its amount in in vitro rhizome grown in soil was $18.14 \%$. Pentadecane; another common compound present in three samples recorded $1.482 \%$ in microrhizome and its amount is increased to $4.49 \%$ in minirhizome oil, while least amount was obtained from in vivo mother rhizome. The amount of pentadecane is comparable to the report [17] wherein the conventional rhizome oil contain $0.57 \%$ and in vitro rhizome grown in the soil has $1.46 \%$ of pentadecane. Here borneol was analysed from micro (1.349\%) and minirhizome oil (3.57\%) samples and it was absent in mother rhizome. However, the amount borneol in our samples are high when compared to the studies [55] that recorded 1.03\% of borneol in essential oil of $K$. galanga.

\section{CONCLUSION}

The active constituents of Kaempferia galanga essential oil are ethyl p-methoxycinnamate, ethyl cinnamate, pentadecane and borneol. Here these compounds were detected from the essential oil samples of in vitro microrhizome and in vivo mother rhizomes and the percentage of abundance of ethyl p- methoxycinnamate was highest in microrhizome oil. Ethyl cinnamate was maximum in minirhizome oil than the other two samples. In our study, in vitro microrhizome and minirhizome essential oil depicted superior quality in terms of the bioactive compounds which is on par with the mother rhizome oil. Thus the findings established here offer the development of a novel method for the extraction of volatile oils from microrhizomes and minirhizomes. This system can be extended for future explorative approaches for drug preparations utilizing the microrhizomes and minirhizomes thereby shortening the gap of demand-supply in the phytoindustrial market.

\section{ACKNOWLEDGEMENTS}

We are thankful to the Principal University College, Thiruvananthapuram for providing the facilities and Director, JNTBGRI, Palode, Thiruvananthapuram, Kerala, India for granting the facilities for GCMS analysis. Also, we acknowledge the research fellowship granted to Vidya VR from the University of Kerala.

\section{Conflicts of interest}

There is no conflict of interest

\section{REFERENCES}

1. Kareem MA. Plants in Ayurveda A compendium of botanical and Sanskrit names. Foundation for Revitalisation of Local Health Tradition (FRLHT). Banglore: India; 1997. P. 240

2. Chen C, Lim YY, Wong SK, Lim KK, Tan SP, Lianto FS, et al. Food Chemistry, 2009; 113:166-172.

3. Sulaiman MR, Zakaria ZA, Duad IA, Hidayat MT. Journal of Natural Medicines, 2008; 62: 221-227.

4. Kochuthressia KP, Britto SJ, Jaseentha MO. International Journal of Biology, Pharmacy and Allied Sciences 2012; 1: 1734-1740.

5. Sivarajan VV, Balachandran I. Ayurvedic drugs and their plant sources. Oxford and IBH publishing, New Delhi; 1994. p. 570.

6. Srivastava KC, Rajana and Amit Chand. Toxicology Reports, 2019; 6: 521-528.

7. Mohanty S, Parida R, Singh S, Joshi RK, Subudhi E, Nayak S. Plant Cell TissueOrgan Culture,2010; 106: 39-46.

8. Kalpana M. Anbazhagan M. Journal of Phytology, 2009; 1:56-61.

9. Wong KC, Qng KS, Lim C L. Flavour and Fragrance Journal, 1992; 7:263-266.

10. Rao VK, Rajasekharan PE, Roy TK, Kumar TV. Journal of medicinal and aromatic plant sciences, 2009; 31:326-329.

11. Ibrahim bin Jantan, Mohd Salleh Mohd Yassin, Chen Bee Chin, Lau Lee Chen, NG Lee Sim. Journal of Pharmaceutical Biology, 2003; 41(5):392-397.

12. Norjit K, Laohakunjit N, Kerdchoechuen O. Molecules, 2007; 12:2047-2060.

13. Tewtrakul S, Yuenyongsawad S, Kummee S, Atsawajaruwan L. Songklanakarin journal of science and technology, 2005; 7(2): 503-507.

14. Xue Y, Chen H. Journal of Hygiene Research, 2002; 31(4): 247-248. 
15. Umar MI, Asmawi MZB, Sadikun A, Altaf R, Iqbal MA. African Journal of Pharmacy and Pharmacology, 2011; 5:1638-1647.

16. Rahman MM, Amin MN, Ahamed T, Ahamad S, Habib IA, Ahmed R, et al. Journal of Biological Sciences, 2005; 5(3):300-304.

17. Sahoo S, Parida R, Singh S, Padhy RN, Nayak. Journal of Acute Disease, 2014; 1:124-130.

18. Choochote W, Kanjanapothi D, Panthanga A, Taesotikul T, Jitpakdi A, Chaithong U, et al. Southeast Asian Journal of Tropical medicine and Public Health, 1999; 30:470-476.

19. Sukari MA, Mohd Sharif NW, Yap ALC, Tang SW, Neoh BK, Rahmani M, et al. Malaysian Journal of Analytical Sciences, 2008; 12:638-644.

20. Huang L, Yagura T, Chen S.Journal of Ethnopharmacology, 2008; 120:123-125.

21. Umar MI, Asmawi MZ, SadikunA, MajidAM., AlSuede FS, Hassan LE, et al. Clinics (Sao Paulo), 2014; 69(2):134-144

22. Othman R, Ibrahim H, Mohd MA, Mustafa M R, Awang K. Phytomedicine, 2006; 13(1-2):61-66.

23. Hong TK, Kim SI, Heo JW, Lee JK, Choi DR. Journal of nematology, 2011;13:235-244.

24. Preetha TS, Hemantha Kumar AS, Padmesh P, Krishnan PN. Journal of Pharmaceutical sciences, 2014; 4:19-23

25. Preetha TS. Journal of Pharmacy and Biological Sciences, 2013; 8(3):19-23.

26. Van den Dool H, Kratz PD. Journal of Chromatography, 1963; 11:463-471.

27. Adams RS. Identification of essential oil components by Gas chromatography/Mass Spectrometry. 4th ed.USA: Allured Publishers; 2007.

28. Ajay Kumar. International journal of pharma and Bio science, 2014; 5(1): 225-231.

29. Priteewagh, MahendraRai, Deshmukh SK, Marta Cristina Teixeira Durate. African journal of biotechnology, 2007; 6 (13):1592-1596.

30. Wen-Cheng Huang, Tsung-Hsien Tsai, Lu-Te Chuang,You-Yi Li, Christos C. Zouboulis, Po-Jung Tsai. Journal of dermatological science, 2014; 73(2014): 232-240.

31. Oforma CC, Udourioh GA, Ojinnaka CM. Journal of Applied Sciences and Environmental management, 2007; 23 (12): 2231-2238.

32. Voller B, Lines E, McCrossin G, Tinaz S, Lungu, C, Grimes G. Journal of Clinical Investigation, 2016; 126:1451-1457.

33. Lowell, Soren Y, Kelley, Richard T, Monahan,
Marika, Hosbach-Cannon, et al. The Laryngoscope. 2018; 129(8):1882-1890.

34. Chanda S, Ramachandra TV. A Journal of Pharmacology, 2019; 9:16-23.

35. Ahmad S, Shabir A, Ahtaram, Muhammad SI, Muhammad SA, Farina Kanwal, et al. Scientific World Journal Hindawi, (2014); 2014: 8

36. Liebert MA. Journal of American atoxicology, 1987; 6:3.

37. Kromhout D, Menotti A, Bloemberg B. Preventive medicine, 1995; 24:308-315.

38. Gupta SK, Banerjee AB, Achari B. Lloydia, 1976; 39:218-222.

39. Kim NJ, Byun SG, Cho JE, Chung K, Ahn YJ. Pest Management Science, 2008; 64:857-862

40. Lakshmanan D, Jim Werngren, Leny Jose, Suja KP, Mangalam SN, R. Luxmi Varma, et al. Fitoterapia, 2011; 82(5):757-61.

41. Liu B, Liu F, Chen C, Gao H. Nat Product Research, 2010; 24:1927-1932.

42. Zhang BY, Lv C, Li WB, Cui ZM, Chen DD and Cao FJ. Chemical and Pharmaceutical Bulletin, 2015; 63:255-262.

43. Peter KV. Handbook of Herbs and Spices Cambridge, GBR. Woodhead Publishing Limited; 2004.

44. Yogeswari S, Ramalakshmi S, Neelavathy, and Muthumary J. Global Journal of Pharmacology, 2012; $6(2): 65-71$.

45. Ekowati J, Hardjono S, Hamid IS. Universamedicina, 2012; 34(1): 43-51.

46. Raina Archana P, Abraham Z. Journal of Essential Oil Research. 2016; 28(1):29:34

47. Yan-Hong Li, Xio-PING Sun, Yin Qing Zang, Ning. The American Journal of Chinese Medicine, 2008; 36: 719-727.

48. Kumar MS, Kumar S, Raja B. Journal of Pharmaceutical \& Biological Archives, 2010; 1(3): 271-27.

49. Liao PC, Ho CL, Wang EI Su Natural Product Communications, 2011; 6:1357-1360.

50. Bhuiyan MD, Begum J, Anwar MN. The Chittagong University Journal of Science, 2008; 3:65-76.

51. Sharma C, Al Kaabi JM, Nurulain SM, Goyal SN, Kamal MA, Ojha S. Current Pharmaceutical Designs, 2016; 22(21):3237-64.

52. Gropper SS, Smith JL, GrofSf JL. Advanced Nutrition and Human Metabolism. 5th ed. 2009. p. 373-1182.

53. Granger RE, Campbell EL, Johnston GA. Biochemical Pharmacology, 2005; 69: 1101-1111. 
54. Fakim AG, Leach D, Wohlmuth $\mathrm{H}$, Naheeda M, Luigino D. Journal of Essential Oil Research, 2002;14:271-273.

55. Sutthanont N, Choochote W, Tuetun B, Junkum A, Jitpakdi A, Chaithong U, et al. Journal of Vector Ecology, 2010; 35:106-115.

56. Miguel MG. Molecules, 2010; 15:9252-9287.
57. Govindarajan M, Benelli G. Journal of Parasitology Research, 2016; 115(7): 2771-2778.

58. Freitas PR, de Araújoa ACJ, Barbosab CRS, Muniza DF, Rochaa JE, Netoa JB, et al. Microbial Pathogenesis, 2020;145: 104223.

59. Sfara V, Zerba EN, Alzogaray RA. Journal of Medical Entomology, 2009; 46(3): 511-515. 